\title{
Distribution of Sugars and Related Enzymes in the Stem and Blossom Halves of 'Valencia' Oranges
}

\author{
Kwan Jeong Song and Ed Echeverria ${ }^{1}$ \\ University of Florida, Institute of Food and Agricultural Sciences, Citrus Research and Education Center, \\ 700 Experiment Station Road, Lake Alfred, FL 33850 \\ Hyoung S. Lee \\ Florida Department of Citrus, 700 Experiment Station Road, Lake Alfred, FL 33850
}

Additional Index words. Citrus sinensis, $\mathrm{CO}_{2}$ fixation, photosynthate partition, sink strength, sucrose synthase

\begin{abstract}
A bstract. The distribution of sugars (sucrose, glucose, and fructose) and related enzymes between the stem and the blossom halves of 'Valencia' oranges [Citrus sinensis (L.) Osbeck] was determined at three stages of fruit development. The blossom half contained significantly higher concentrations of sugars during later stages of development and maturation (12\% and $20 \%$, respectively). Neither the enzyme marker for sucrose synthesis [sucrose-phosphate synthase (SPS)] nor enzymes of $\mathrm{CO}_{2}$ fixation (NADP-malic enzyme, PEP carboxylase, and PEP carboxykinase) were significantly different between the halves. Sucrose synthase (SS), the enzymatic marker for sink strength, had significantly higher activity in the blossom half during later stages of fruit development when rapid sugar accumulation takes place. These data suggest that differential distribution of sugars between the stem and the blossom halves of citrus fruit is, in part, the result of differential sink strength.
\end{abstract}

Asymmetric distribution of soluble solids in citrus fruit has been described not only among fruit within individual trees (Syvertsen and Albrigo, 1980), but within individual fruit as well (Bartholomew and Sinclair, 1946; Blondel, 1952; Hall, 1955; Ting, 1969). Inside the fruit, soluble solids and total sugars are found in an increasing gradient toward the blossom end (away from the pedicel) (Bartholomew and Sinclair, 1946; Ting, 1969) and on an outwardly radial direction (Blondel, 1952; Hall, 1955). Bartholomew and Sinclair (1946) reported that mature oranges and grapefruit had considerably higher concentrations of soluble solids in the blossom halves than in the stem halves (stem half of the fruit refers to the half closer to the pedicel, whereas the blossom half is that away from the pedicel). Ting (1969) also observed an ubiquitous increase in nonreducing sugars and total sugars along the axis of the fruit from the stem end to the blossom end. Immature fruit, however, showed no such gradient. Unequal sugar distribution in mature fruit has also been reported for peaches (Prunus persica), melons (Cucurbita pepo), and apples (Malus pumila) (Harding, 1936; Martin, 1954).

In citrus fruit, sugar content increases rapidly during development (Harding and Fisher 1945; Lowell et al., 1989; Tadeo et al., 1987) resulting from an increase in photoassimilate supply and a decrease in sugar consumption as respiratory rates decline. Despite the fact that most photoassimilates that accumulate in the juice cells come from photosynthetic source leaves (Goldschmidt and Koch, 1996; Yen and Koch, 1990), several intracellular processes could affect the ultimate concentration of stored sugars. For example, intracellular sucrose catabolism could directly determine sink strength (Ho, 1988; Sung et al., 1989) and, consequently, the sugar levels (Balibrea et al., 1996). Similarly, sucrose resynthesis can potentially alter the balance between sucrose breakdown and synthesis, directly affecting the accumulation process (Hubbard et al., 1989). Sucrose synthesis has been directly associated

Received for publication 21 July 1997. Accepted for publication 26 Jan. 1998. Florida Agricultural Experiment Station journal series no. R-05870. The cost of publishing this paper was defrayed in part by the payment of page charges. Under postal regulations, this paper therefore must be hereby marked advertisement solely to indicate this fact.

${ }^{1}$ To whom reprint requests should be addressed. with the process of sucrose storage in other sucrose importing and storing tissues such as sugarbeet (Beta vulgaris) (Fiew and Willenbrink, 1991) and melon species (Hubbard et al., 1989). Dark $\mathrm{CO}_{2}$ fixation, which has been reported to occur during light and dark hours throughout development of citrus fruit (Yen and Koch, 1990), could potentially contribute to the long-term sugar allocation. Another potential factor that may affect the final sugar concentrations in citrus juice cells is the extent and arrangement of the vascular supply.

Despite the long recognition of uneven distribution of soluble solids and sugar in citrus fruit, there are no reports, to our knowledge, examining potential factors involved. This study investigates possible causes for unequal sugar distribution in 'Valencia' oranges by examining the allocation of enzymes determinant of sink strength, sucrose synthesis, and $\mathrm{CO}_{2}$ fixation. Sink strength at the enzyme level (as discussed in this work) refers to the series of enzymatic reactions associated with sucrose storage or its interconversion.

\section{Materials and Methods}

Plant material. 'Valencia' oranges (Citrus sinensis [L.] Osbeck) were obtained from mature trees in orchards at the Citrus Research and Education Center, Lake Alfred, Fla., during the 1995 and 1996 growing seasons. All fruit were sampled from the outside southern canopy in the morning and used immediately for enzyme extraction and sugar analysis. Sampling was conducted at three arbitrary stages of fruit development separated by 2 months each starting in September; September fruit = green (not final size); November fruit = green (final fruit size attained, yellow inside); January fruit $=$ yellow (faster rates of sugar accumulation).

Forenzyme extraction, fruit were washed, cut equatorially, peeled, and separated into individual segments or segment halves. Juice sacs were separated from the segment wall, rinsed, and blotted dry before homogenization. For sugar analysis, fruit halves were squeezed separately and the extract immediately neutralized with $1 \mathrm{~N} \mathrm{NaOH}$.

Sugar analysis. Sugar analysis was accomplished by highperformance liquid chromatography as described by Lee and Nagy (1988), but purification with Chrom-prep mixed resin was omitted. The neutralized juice was diluted with water (1:1) and centri- 
Table 1. Sugar content of tissue extract in the stem and blossom halves of 'Valencia' orange fruit at three stages of development. Each value is the mean of five experiments \pm SD.

\begin{tabular}{lccc}
\hline \hline & & Sampling date \\
\cline { 2 - 4 } & September & November & January \\
\cline { 2 - 4 } Sugar & & Sugar content $\left(\mathrm{g} \cdot \mathrm{L}^{-1}\right)$ \\
\hline Stem half & $16.3 \pm 1.4$ & & \\
$\quad$ Fructose & $15.1 \pm 1.5$ & $18.6 \pm 01.9$ & $2.07 \pm 0.10$ \\
Glucose & $20.4 \pm 2.8$ & $16.6 \pm 02.1$ & $1.75 \pm 0.12$ \\
Sucrose & $51.8 \pm 2.8$ & $32.4 \pm 4.0$ & $4.16 \pm 0.40$ \\
Total & 1.54 & $67.5 \pm 4.8$ & $79.6 \pm 3.8$ \\
Hexoses and sucrose & & 1.09 & 0.92 \\
Blossom half & $17.9 \pm 1.2$ & $22.3 \pm 1.6^{*}$ & $25.8 \pm 1.4^{*}$ \\
Fructose & $17.0 \pm 1.2$ & $20.6 \pm 1.3^{*}$ & $23.2 \pm 1.0^{* * * *}$ \\
Glucose & $18.7 \pm 2.2$ & $33.0 \pm 3.9$ & $49.5 \pm 3.7^{*}$ \\
Sucrose & $53.6 \pm 4.3$ & $75.9 \pm 2.7^{*}$ & $98.5 \pm 4.2^{* *}$ \\
Total & 1.87 & 1.30 & 1.02 \\
Hexoses and sucrose & & & \\
* $^{* * *}$ Significant at $P<0.05$ or 0.01, respectively & & & \\
& & &
\end{tabular}

Table 2. Sugar content of tissue extract in the sunny and shaded halves of 'Valencia' orange fruit at three stages of development. Each value is the mean of five experiments \pm SD.

\begin{tabular}{lccc}
\hline & & Sampling date & \\
\cline { 3 - 4 } & September & November & January \\
\cline { 3 - 4 } Sugar & & Sugar content $\left(\mathrm{g} \cdot \mathrm{L}^{-1}\right)$ \\
\hline Sunny half & $16.4 \pm 0.8$ & & \\
$\quad$ Fructose & $15.4 \pm 0.7$ & $21.0 \pm 1.8$ & $21.9 \pm 2.3$ \\
Glucose & $17.0 \pm 1.6$ & $18.9 \pm 1.7$ & $19.3 \pm 2.5$ \\
Sucrose & $48.8 \pm 2.1$ & $30.6 \pm 5.7$ & $43.4 \pm 0.39$ \\
Total & 1.87 & $69.7 \pm 7.6$ & $84.6 \pm 4.6$ \\
Hexoses and sucrose & & 1.30 & 0.95 \\
Shady half & $15.7 \pm 0.6$ & & $21.9 \pm 2.2$ \\
Fructose & $14.9 \pm 0.7$ & $20.2 \pm 1.7$ & $19.6 \pm 2.1$ \\
Glucose & $16.9 \pm 0.17$ & $18.1 \pm 0.8$ & $47.0 \pm 2.7$ \\
Sucrose & $46.5 \pm 4.3$ & $32.6 \pm 0.38$ & $88.5 \pm 4.8$ \\
Total & 1.81 & $70.5 \pm 5.2$ & 0.88 \\
Hexoses and sucrose & 1.17 & \\
\hline
\end{tabular}

fuged at $12,000 g_{n}$ for $10 \mathrm{~min}$. Five milliliters of the supernatant were passed though a water C-18 Sep-Pak cartridge and further filtered through 0.8- to 0.2- $\mu \mathrm{m}$ Acrodisc PF filter (Gelman Science, Ann Arbor, Mich.) before injection. The sugars were eluted into a Zorbax $\mathrm{NH}_{2}$ column $(4.6 \mathrm{~mm} \times 25 \mathrm{~cm})$ isocratically with a mobile phase of 75 acetonitrile : 25 water $(\mathrm{v} / \mathrm{v})$ at a flow rate of 1 $\mathrm{mL} \cdot \mathrm{min}^{-1}$. The eluate was monitored by a refractive index (RI) detector (HP 1037A). Data values are from five separate experiments. Each experiment was conducted in triplicates and consisted of combined extracts of three different fruit.

ENZYME EXTRACTION AND ASSA YS. Four grams of juice sac tissue were homogenized in a prechilled mortar and pestle with $10 \mathrm{~mL}$ of a buffered solution containing $0.4 \mathrm{M}$ Hepes ( $N$-[2-hydroxyethyl] piperazine- $N^{\prime}$-[2ethanesulfonic acid])/KOH buffer $(\mathrm{pH} .7 .5), 20$ $\mathrm{mM} \mathrm{MgCl}_{2}, 0.5 \mathrm{~mm}$ PMSF (phenylmethylsulfonyl fluoride), $2 \mathrm{~mm}$ EDTA (ethylenediaminetetraacetic acid), $20 \%$ (v/v) glycerol, $2 \%$ $(\mathrm{v} / \mathrm{v})$ ethylene glycol, $20 \mathrm{~mm}$ mercaptoethanol, $0.2 \%$ aprotinin, and $3 \%(\mathrm{w} / \mathrm{v})$ PVP-40 (polyvinylpyrrolidone). The resulting mixture was centrifuged for $5 \mathrm{~min}$ at $13,000 \mathrm{~g}_{\mathrm{n}}$, filtered through glasswool, and centrifuged again for $15 \mathrm{~min}$ at $25,000 \mathrm{~g}$. Of the supernatant, $2.5 \mathrm{~mL}$ were desalted by passing it through a Sephadex G-25 column pre-equilibrated with $20 \mathrm{mM}$ Hepes/KOH buffer ( $\mathrm{pH} 7.2$ ),
$10 \mathrm{~mm} \mathrm{MgCl}_{2}, 10 \%$ (v/v) glycerol, and $5 \mathrm{~mm}$ mercaptoethanol. Enzyme extractions were carried out at $4{ }^{\circ} \mathrm{C}$.

Sucrose-phosphate synthase (SPS, EC. 2.4.1.14) reactions were initiated by adding $80 \mu \mathrm{L}$ of desalted plant extract to a reaction mixture containing $7.7 \mathrm{~mm}$ fru-6-P, $19.3 \mathrm{~mm} \mathrm{MgCl}_{2}, 28.2 \mathrm{~mm}$ glc6-P, 7.1 mM UDP-glc (uridine 5'-diphosphoglucose), and $62 \mathrm{~mm}$ Hepes/KOH (pH 7.5) in a total volume of $240 \mu \mathrm{L}$ as described by Salvucci et al. (1990). For sucrose synthase (SS, EC. 2.4.1.13), the reaction consisted of $10 \mathrm{~mm}$ fructose, $5 \mathrm{~mm} \mathrm{MgCl}, 2 \mathrm{~mm}$ UDPglucose, $100 \mathrm{~mm}$ Hepes/KOH (pH 7.2), and $80 \mu \mathrm{L}$ plant extract in a final volume of $1 \mathrm{~mL}$. All reactions were carried out at $30^{\circ} \mathrm{C}$. At determined times, reactions were terminated by boiling $60 \mu \mathrm{L}$ aliquots for $2 \mathrm{~min}$. The product sucrose was measured by the anthrone method of Van Handel (1968); UDP was measured as described by Salvucci et al. (1990). Preliminary research had indicated that the activity of SS in the synthetic direction at $\mathrm{pH} 7.2$ was equivalent to the breakdown activity at $\mathrm{pH}$ optimum of 6.5 . For reasons of simplicity, SS was therefore assayed in the synthetic direction.

Malic enzyme activities (NAD-malic enzyme, EC 1.1.1.38; and NADP-malic enzyme, EC 1.1 .1 .40 ) were measured at $340 \mathrm{~nm}$ by following the continuous reduction of $\mathrm{NAD}^{+} \beta$-nicotinamide ad- 
Table 3. Activities of enzymes of sucrose synthesis (SPS), expressed as sucrose synthesized or hydrolyzed (protein basis) and sink strength (SS) at the stem and blossom halves of 'Valencia' juice tissue. Values are the mean of five experiments \pm SD.

\begin{tabular}{lccc}
\hline & & \multicolumn{2}{c}{ Sampling date } \\
\cline { 2 - 4 } & September & November & January \\
\cline { 2 - 4 } Enzyme & & Activity $\left(\mu \mathrm{mol} \cdot \mathrm{min}^{-1} \cdot \mathrm{mg}^{-1}\right)$ & \\
\hline Stem half & & & \\
$\quad$ SPS & $25.64^{*} \pm 0.60$ & $22.75 \pm 2.65$ & $18.36 \pm 1.39$ \\
SS & $25.94 \pm 0.99$ & $26.35 \pm 1.24$ & $26.43 \pm 1.45$ \\
Blossom half & & & \\
$\quad$ SPS & $23.80 \pm 1.04$ & $21.70 \pm 2.50$ & $18.22 \pm 1.62$ \\
SS & $26.17 \pm 0.47$ & $28.01^{*} \pm 1.77$ & $29.97^{* *} \pm 0.64$ \\
\hline
\end{tabular}

${ }^{* * * *}$ Significant at $P<0.05$ or 0.01 , respectively.

Table 4. Activities (protein basis) of enzymes of $\mathrm{CO}_{2}$ fixation from 'Valencia' orange juice cells at two stages of development. Value are the mean of three experiments $\pm \mathrm{SD}$.

\begin{tabular}{lcccc}
\hline \hline & \multicolumn{2}{c}{ November } & \multicolumn{2}{c}{ January } \\
\cline { 2 - 5 } & Stem half & Blossom half & Stem half & Blossom half \\
\cline { 2 - 5 } & \multicolumn{4}{c}{ Activity $\left(\mathrm{nmol} \cdot \mathrm{min}^{-1} \cdot \mathrm{mg}^{-1}\right)$} \\
\hline NADP-malic enyzme & $219.6 \pm 20.5$ & $239.4 \pm 2.14$ & $136.5 \pm 23.4$ & $145.3 \pm 22.8$ \\
PEP-carboxylase & $24.36 \pm 1.4$ & $26.9 \pm 2.3$ & $15.5 \pm 2.7$ & $15.7 \pm 4.3$ \\
PEP-carboxykinase & $29.8 \pm 8.9$ & $32.9 \pm 7.3$ & $16.2 \pm 11.4$ & $17.8 \pm 0.9$ \\
\hline
\end{tabular}

enine dinucleotide) or $\mathrm{NADP}^{+} \beta$-nicotinamide adenine dinucleotide phosphate), respectively, as in Cook et al. (1995). PEP (phosphoenol pyruvate) carboxylase (EC 4.1.1.38; Zhang et al., 1995) and PEP carboxykinase (EC 4.1.1.49; Ray and Black, 1976) were determined by coupling the formation of the product oxaloacetate with commercial malic dehydrogenase (EC 1.1.1.37; Sigma M-9004). The spectrophotometric method of Ishibashiet al. (1996) was used for Rubisco (EC 4.1.1.39) measurements. Protein was determined by the coomassie blue method of Bradford (1976). Data values are from five separate experiments. Each experiment was conducted in triplicates and consisted of combined extracts of two fruit.

\section{Results}

Sugar CONTENT IN DIfFerent portions of THE FRUIT. Total sugar increased $>50 \%$ in the stem half and $\approx 90 \%$ in the blossom half of Valencia oranges between September and January (Table 1). At all three developmental stages, the blossom half contained higher levels of total sugars than the stem half, although only the last two stages were statistically different $(P<0.05)$. In January, the blossom half contained $24 \%$ more total sugars than the stem half. In comparison, the differences in total sugars between the blossom and stem half were only $4 \%$ in September and $12 \%$ in November.

The concentrations of all three individual sugars increased during development in both halves. Overall, sucrose increased an average of $130 \%$ whereas hexoses increased approximately $30 \%$. At maturity (January), each sugar was found at higher concentrations at the blossom half (Table 1). There were no significant differences in total or individual sugars between the sunny side and the shady side of the fruit (Table 2). The lack of differences in sugar composition between the sunny and shady side regardless of any light intensity variations, and the fact that peel photoassimilates are not transported inward into the juice cells (Yen and Koch, 1990) eliminate fruit photosynthesis as a possible cause of unequal sugar distribution.
ENZYME ACTIVTTIES IN DIFFERENT PORTIONS OF THE FRUIT. The activities of SPS and SS, established as the major mechanisms for sucrose synthesis (Huber and Huber, 1996; Stitt and Sonnewald, 1995) and determinant of sink strength (Ho, 1988; Sung et al., 1989), respectively, are presented in Table 3 . There was a continuous decline in the specific activity of SPS expressed as sucrose synthesized on a protein basis $\left(\mu \mathrm{mol} \cdot \mathrm{min}^{-1} \cdot \mathrm{mg}^{-1}\right)$ during development of both halves. Nonetheless, there were significant levels of SPS activity at maturity. Similar patterns were observed on a fresh mass basis $\left(\mu \mathrm{g} \cdot \mathrm{min}^{-1} \cdot \mathrm{g}^{-1}\right)$. Protein content (total protein) was similar in both halves. Although there were no significant differences in SPS activity between the two halves at maturity, activity tended to be higher in the stem half earlier in development. In contrast, the activity of SS was consistently higher at the blossom half throughout fruit development. While SS activity remained fairly constant in stem half, it increased continuously in the blossom half throughout development. Specific activities of both enzymes were very similar to those reported by Lowell et al. (1989) for grapefruit (Citrus paradisi) juice cells.

Of the five enzymes with capacity to fix $\mathrm{CO}_{2}$, Rubisco and NAD-malic enzyme were not detected in juice tissue. The remaining enzymes (NADP-malic enzyme, PEP carboxylase and PEP carboxykinase; Table 4) showed declining levels of activity from green fruit to maturity. NADP-malic enzyme had the highest maximal activity. In all instances, there were no differences between the blossom and the stem halves in any of these three enzymes.

\section{Discussion}

Although sucrose enters citrus juice cells without significant levels of apoplastic inversion (Koch and Avigne, 1990), several intracellular events may affect the final concentration of stored assimilates. Differences in any (or a combination) of these posttransport events between cells or different portions of the organ may result in gradients of accumulated sugars. Our data indicate that in 'Valencia' orange fruit the activity of SS in the juice cells 
of the blossom half is significantly higher than in the stem half (Table 3). The difference in SS activity is notable since it indicates a higher sink strength during the stages of sugar accumulation. In sucrose importing organs (regardless of whether the imported sucrose is stored as sucrose, hexoses or starch) the regulation of sucrose cleavage within the cells constitutes the biochemical marker of sink strength (Ho, 1988; Ho et al., 1991; Sung et al., 1989). Our evidence is in agreement with this concept. The higher levels of SS activity in the juice cells at blossom half of 'Valencia' oranges are paralleled by significantly higher levels of stored sugars (Table 1). The fact that the hexoses to sucrose ratio always remained higher in the blossom half supports this contention. For sink cells storing sucrose in the vacuole (as Valencia orange juice cells; Echeverria and Valich, 1988), sucrose cleavage by SS in the cytosol may not be required to facilitate transport across the tonoplast, but instead would be necessary to produce hexoses and sugar nucleotides for respiration and for other cellular events as demonstrated in sugarbeet tap roots (Kursanov et al., 1989).

Sink strength encompasses the collective capacity for sucrose breakdown which includes SS, total invertase activity, and in the case of acidic cells, vacuolar acid hydrolysis (Echeverria and Burns, 1989). In sweet orange, grapefruit, and lime juice cells, both particulate and soluble acid invertases disappear very early in fruit development (Echeverria, 1990; Echeverria et al., 1997; Kato and Kubota, 1978; Lowell et al., 1989). Alkaline invertase activity, although present at all stages, was always lower than the activity of SS $(<5 \%)$ especially during the sugar accumulation periods (data not shown). Therefore, SS was regarded as the key determinant enzyme of sink strength as has been previously reported for other tissues (Black et al., 1995, and references therein).

Acid hydrolysis of sucrose in the vacuole plausibly contributes significantly to the production of hexoses considering the low vacuolar $\mathrm{pH}$ of orange juice cells (estimated at 2.8; Echeverria and Burns, 1989). In fact, such hydrolysis may account for most of the hexoses present in the vacuole (Echeverria and Valich, 1988) but is an unlikely factor in differential sugar allocation since the acidity in citrus fruit is equally distributed between the stem and blossom halves (Ting, 1969). Other possible factors that may have contributed to differential sugar allocation between the two halves, such as higher rates of sucrose synthesis (Table 3) and dark $\mathrm{CO}_{2}$ fixation (Table 4), were not significantly different (or in some instances, even higher in the stem half as for SPS). Both processes are known to take place in citrus juice cells (Lowell et al., 1989; Yen and Koch, 1990) and could have affected the total sugar content.

Whether the higher levels of SS activity (and resultant larger sink strength) in the blossom half of 'Valencia' orange fruit are the direct cause or the result of elevated sugar transport levels can not be determined. Genes for sucrose metabolic enzymes can be affected by high sugar levels in importing tissues (Koch, 1996). Sucrose synthase gene expression has been reported to be enhanced in the presence of abundant carbohydrate supply in rice (Oryza sativa) (Kerrer and Rodriguez, 1992), potato (Solanum tuberosum) (Salanoubat and Belliard, 1989), and sweetpotato (Ipomoea batatas) (Nakamura et al., 1991). A differential vascular network with a more abundant phloem supply to the blossom half could lead to higher levels of SS. In either case, the higher levels of SS in the blossom half of 'Valencia' orange juice tissue represent a stronger sink that consequently results in higher levels of stored sugars.

\section{Literature Cited}

Balibrea, M.E., A.M. Santa Cruz, M.C. Bolarin, and F. Perez-Alfocea. 1996. Sucrolytic activities in relation to sink strength and carbohydrate composition in tomato fruit growing under salinity. Plant Sci. 118:4755.

Bartholomew, E.T. and W.B. Sinclair. 1946. Unequal distribution of soluble solids in the pulp of citrus fruits. Plant Physiol. 16:293-312.

Black, C.C., T. Loboda, J-Q. Chen, and S-J. Sung. 1995. Can sucrose cleavage enzymes serve as markers for sink strength and is sucrose a signal molecule during plant sink development?, p. 49-54. In: H. Pontis, G.L. Salerno and E. Echeverria (eds.). Sucrose metabolism, biochemistry, physiology and molecular biology. Curr. Topics in Plant Physiol. vol. 14.

Blondel, L. 1952. Determination of the maturity of citrus fruits. Ann. Inst. Agr. et Serv. Researcher et Exp. Agr. Algerie 7:1-56.

Bradford, M.M. 1976. A rapid and sensitive method for the quantitation of microgram quantities of protein using the principle of dye binding. Ann. Biochem. 72:143-147.

Cook R.M., J.G. Lindsay, M.B Wilkins, and H.G Nimmo. 1995. Decarboxylation of malate in the crassulacean acid metabolism plant Bryophyllum (Kalanchoe) fedtschenkoi. Plant Physiol. 109:1301-1307.

Echeverria, E. 1990. Developmental transition from enzymatic to acid hydrolysis of sucrose in acid limes (Citrus aurantifolia). Plant Physiol. 92:168-171.

Echeverria, E. and J.K. Burns. 1989. Vacuolar acid hydrolysis as a physiological mechanism for sucrose breakdown. Plant Physiol. 90:530533.

Echeverria, E., P.C. Gonzalez, and A. Brune. 1997. Characterization of proton and sugar transport at the tonoplast of sweet lime (Citrus limmetioides) juice cells. Physiol. Plant. 101:291-300.

Echeverria, E. and J. Valich. 1988. Carbohydrate and enzyme distribution in protoplasts from Valencia orange juice sacs. Phytochem. 27:73-76.

Fiew, S. and J. Willenbrink. 1991. Sugar transport and sugar metabolizing enzymes in sugar beet storage roots (Beta vulgaris ssp. altissima). J. Plant Physiol. 137:216-223.

Goldschmidt, E.E. and K.E. Koch. 1996. Citrus, p. 797-823. In: E. Zamski and A.A. Shaffer (eds.). Photoassimilate distribution in plants and crops: Source sink relationships. Marcel Dekker Inc., New York.

Hall, E.G. 1955. Juice of oranges. Food Preserv. Q. 15:12-14.

Harding, P.L. 1936. Distribution of total soluble solids and catalase in different parts of Jonathan apples. J. Agr. Res. 53:43-48.

Harding, P.L. and D.F. Fisher. 1945. Seasonal changes in Florida grapefruit. USDA Tech. Bul. 886:1-100.

Ho, L.C. 1988. Metabolism and compartmentation of imported sugars in sink organs in relation to sink strength. Ann. Rev. Plant Physiol. 39:355378.

Ho, L.C., A. Lecharny, and J. Willenbrink. 1991. Sucrose cleavage in relation to import and metabolism of sugars in sink organs, p. 178-186. In: J.L. Bonnemian, S. Delrot, W. Lucas and J Dainty (eds.). Recent advances in phloem transport and assimilate compartmentation. Ouest Editions, Presses Academiques, Paris.

Hubbard, N.L., S.C. Huber, and D.M. Pharr. 1989. Sucrose phosphate synthase and acid invertase as determinants of sucrose concentration in developing muskmelon (Cucumis meloL.) fruits. PlantPhysiol.91:15271534.

Huber, S.C. and J.L. Huber. 1996. Role and regulation of sucrosephosphate synthase in higher plants. Annu. Rev. Plant Physiol. Plant Mol. Biol. 47:431-444.

Ishibashi M., H. Usuda, and I. Terashima. 1996. The loss of ribulose-1,5bisphosphate carboxylase/oxygenase caused by 24-h rain treatment fully explains the decease in photosynthetic rate in bean leaves. Plant Physiol. 111:635-640.

Kato, T. and S. Kubota. 1978. Properties of invertases in sugar storage tissues of citrus fruit and changes in their activities during maturation. Physiol. Plant. 42:67-72.

Kerrer, E.E. and R.L. Rodriguez. 1992. Metabolic regulation of rice $\alpha$ amylase and sucrose synthase genes in planta. Plant J. 2:517-523.

Koch, K.E. 1996. Carbohydrate-modulated gene expression in plants. Annu. Rev. Plant Physiol. Plant Mol. Biol, 47:509-540.

Koch, K.E. and W.T. Avigne. 1990. Postphloem, non-vascular transfer in citrus: Kinetics, metabolism and sugargradients. Plant Physiol. 93:14051416. 
Kursanov, A.L., M.F. Prasolova, and O.A. Pavlinova. 1989. Enzymatic sucrose conversion routes in sugar beet root in relation to sink function. Fiziol Rast. 36:629-641.

Lee, H.S. and S. Nagy. 1988. Quality changes and non-enzymatic browning intermediates in grapefruit juice during storage. J. Food Sci. 53:168-172.

Lowell, C.A., P.T. Tomlinson, and K.E. Koch. 1989. Sucrose-metabolizing enzymes in transport tissues and adjacent sink structures in developing citrus fruit. Plant Physiol. 90:1394-1402.

Martin, D. 1954. Variation between apple fruits and its relation to keeping quality. II. Between-tree variations due to cropping factors. Austral. J. Agr. Res. 5:9-30.

Nakamura K., M. Ohto, N. Yoshida, and K. Nakamura. 1991. Sucroseinduced accumulation of $\alpha$-amylase occurs concomitant with the accumulation of starch and sporamin in leaf-petiole cuttings of sweet potato. Plant Physiol. 96:902--912.

Ray, T.B. and C.C. Black. 1976. Characterization of phosphoenolpyruvate carboxylase from Panicum maximum. Plant Physiol. 58:603-607.

Salanoubat, M. and G. Bclliard. 1989. The steady-state level of potato sucrose synthase m-RNA is dependent on wounding, anaerobiosis and sucrose concentration. Gene 84:181-185.

Salvucci, M.E., R.R. Drake, and B.E. Haley. 1990. Purification and photoaffinity labeling on sucrose-phosphate synthase from spinach leaves. Arch. Biochem. Biophys. 281:212-218.

Stitt, M. and U. Sonnewald. 1995. Regulation of metabolism in transgenic plants. Annu. Rev. Plant Physiol. Plant Mol. Biol. 46:341-368.

Sung, S.J.S., D.P. Xu, and C.C. Black. 1989. Identification of actively filling sucrose sinks. Plant Physiol. 89:1117-1121.

Syvertsen, J.P. and L.G. Albrigo. 1980. Some effects of grapefruit tree canopy position on microclimate, water relations, fruit yield, and juice quality. J. Amer. Soc. Hort. Sci. 105:454-459.

Tadeo J.L., J.M. Ortiz, and A. Estelles. 1987. Sugar changes in Clementine and orange fruit during ripening. J. Hort. Sci. 62:531-537.

Ting, S.V. 1969. Distribution of soluble components and quality factors in the edible portion of citrus fruits. J. Amer. Soc. Hort. Sci. 94:515-519. Van Handel,E. 1968. Direct microdetermination of sucrose. Anal. Biochem. 22:280-283.

Yen, C-R. and K.E. Koch. 1990. Developmental changes in translocation and localization of ${ }^{14} \mathrm{C}$ - labeled assimilates in grapefruit: Light and dark $\mathrm{CO}_{2}$ fixation by leaves and fruit. J. Amer. Soc. Hort. Sci. 115:815-819. Zhang X.Q., B. Li, and R. Chollet. 1995. In vivo regulatory phosphorylation of soybean nodule phosphoenolpyruvate carboxylase. Plant Physiol. 108:1561-1568. 